\title{
Growth curve by Gompertz nonlinear regression model in female and males in tambaqui (Colossoma macropomum)
}

\author{
FERNANDA DE MELLO ${ }^{1}$, CARLOS A.L. OLIVEIRA ${ }^{2}$, RICARDO P. RIBEIRO ${ }^{2}$, EMIKO K. RESENDE ${ }^{3}$, JAYME \\ A. POVH ${ }^{4}$, DARCI C. FORNARI ${ }^{2}$, ROGÉRIO V. BARRETO ${ }^{2}$, CONCEPTA MCMANUS ${ }^{1}$ and DANILO STREIT JR ${ }^{1}$ \\ ${ }^{1}$ Departamento de Zootecnia, Universidade Federal do Rio Grande do Sul, Avenida \\ Bento Gonçalves, 7712, 91540-000 Porto Alegre, RS, Brasil \\ ${ }^{2}$ Departamento de Zootecnia, Universidade Estadual de Maringá, Avenida Colombo, 5790, 87020-900 Maringá, PR, Brasil \\ ${ }^{3}$ Embrapa Pantanal, Rua 21 de Setembro, 1880, 79320-900 Corumbá, MS, Brasil \\ ${ }^{4}$ Faculdade de Medicina Veterinária e Zootecnia, Universidade Federal do Mato Grosso do \\ Sul, Avenida Senador Filinto Müller, 2443, 79074-460 Campo Grande, MS, Brasil
}

Manuscript received on July 2, 2014; accepted for publication on April 29, 2015

\begin{abstract}
Was evaluated the pattern of growth among females and males of tambaqui by Gompertz nonlinear regression model. Five traits of economic importance were measured on 145 animals during the three years, totaling 981 morphometric data analyzed. Different curves were adjusted between males and females for body weight, height and head length and only one curve was adjusted to the width and body length. The asymptotic weight $(a)$ and relative growth rate to maturity $(k)$ were different between sexes in animals with $\pm 5 \mathrm{~kg}$; slaughter weight practiced by a specific niche market, very profitable. However, there was no difference between males and females up to $\pm 2 \mathrm{~kg}$; slaughter weight established to supply the bigger consumer market. Females showed weight greater than males $( \pm 280 \mathrm{~g})$, which are more suitable for fish farming purposes defined for the niche market to larger animals. In general, males had lower maximum growth rate ( $8.66 \mathrm{~g}$ / day) than females $(9.34 \mathrm{~g}$ / day), however, reached faster than females, 476 and 486 days growth rate, respectively. The height and length body are the traits that contributed most to the weight at 516 days $(P<0.001)$.
\end{abstract}

Key words: Gompertz curve, body growth, maximum growth rate, slaughtered point.

\section{INTRODUCTION}

Tambaqui (Colossoma macropomum: CUVIER, 1818) is a native species of Amazon basin with a highest production at continental aquaculture, a expressive demand and growing in Brazil (Ministério da Pesca e Aquicultura 2013). Due to its large

Correspondence to: Fernanda de Mello

E-mail: Fernandade.mello@gmail.com importance to aquaculture, many studies have been conducted evaluating diets and metabolism (Corrêa et al. 2007), reproduction (Carneiro et al. 2012, Maria et al. 2012), genetics (Gomes et al. 2012, Hamoy and Santos 2012, Marcuschi et al. 2010), among others; however, few is known about their growth pattern (Penna et al. 2005).

Multiple factors affect the efficiency of the animal growth in fish farm, such as genetics, sex, 
nutrition and environment (Oliva-Teles 2012). Animal growth patterns can be modified by selection; thus, the knowledge about the speed of growth of different tissues has high value to the meat production industry (Ibáñez-Escriche and Blasco 2011). The knowledge on body growth has strategic importance for genetic improvement; besides providing information to animal selection based in important economic traits can be used to predict or fit the optimal slaughter age (Knizetova et al. 1991). Similarly, the prior knowledge on body growth enables detect others important aspects, for example sexual dimorphism, allowing adapt the processing techniques of meat in accordance with each sex (Contreras-Guzmán 1994, Gomiero et al. 2003).

A form to predict and evaluate the animal body growth is by growth curves study from individual growth curves. The usual models applied to describe growth are based on differential equations that seek a biological interpretation (Arango and Van Vleck 2002). Different non-linear equations are used in animal production to describe the animal growth over time with different biological interpretation meaning related to initial conditions, growth rate, or adult body weight, all linked to economic aspects of production.

In order to estimate body growth of the tambaqui and evaluate differences between males and females was used the Gompertz nonlinear regression model. This model is an most appropriate nonlinear equation to describe the tambaqui growth, together with the Logistic model (Costa et al. 2013). However, Gompertz model has desirable properties in a growth curve, which unlike other functions, initial and always greater than zero body mass, which reflects the fact that the animal already born with some mass (Fialho 1999). Gompertz model has only three parameters, equivalent in number to a quadratic function. However, it fits better and the growth curve can be used in a time interval that covers the entire life of animal.

\section{MATERIALS AND METHODS}

Were analyzed 981 biometric data from 145 animals measured for three years (2009 - 2011) for economic important traits. All procedures were carried out according to the international practices for animal use and care under the control of an internal committee of the Universidade Federal do Rio Grande do Sul, Brazil. The offspring of each family remained in the same environment until it reached a body weight of $20 \mathrm{~g}$ (more or less 1 month) when it was possible to mark the animals by Passive Integrated Transponder Tags (PIT) in the dorsal muscle. After, the animals were transferred to earth ponds tank $\left(500 \mathrm{~m}^{2}\right)$ remained during the whole period with alimentation two-fold per day up to apparent satiation. Were measured body weight (BW) (grams), length of head (LH) (cm) (from anterior end of the head and caudal operculum), body width $(\mathrm{BWi})(\mathrm{cm})$ (from $1^{\text {st }}$ dorsal fin ray), body height $(\mathrm{BH})(\mathrm{cm})$ (from $1^{\text {st }}$ dorsal fin ray) and body length $(\mathrm{BL})(\mathrm{cm})$ by pachymeter, ictiometer and measuring tape graduated $(\mathrm{mm})$.

Gompertz nonlinear regression model was used to describe growth curves in tambaqui sorted by sex. This can be described as, $y=a \cdot e^{(-e)^{(-b(t-k))}}$, where, $y$ represents the interest trait, $a$ is the maximum value of $y$ (asymptotic values), $b$ is a constant rate of exponential growth, $e$ is the base of natural logarithms, $t$ is the age in days and $k$ is the age at inflection point. The growth rate ( $\mathrm{g} /$ day) is given by the derivative of the above (Fialho 1999): $\frac{d y}{d t}=a \cdot b \cdot e^{-b(t-k)-e^{-b(t-k)}}$.

Were tested the curve adequacy for each trait using eight equations to obtain the best fit for Gompertz model parameters in population, i.e., it would be better to set a single curve for the entire population or one curve for each sex. The adequacy test was performed using an adaptation of likelihood ratio test proposed by Regazzi (Regazzi and Silva 2004). A simple equation, called M8, considered the Gompertz parameters were the same at males and females; and a complete equation, called M1, 
considered a specific parameter for each sex; other models tested were simplifications of M1 equation (Table I). Gompertz model parameters estimate was carried out by NLIN (Nonlinear Regression Models) procedure; regression analysis was carried out by GLM (Generalized Linear Model) procedures and the principal factor analysis was performed by FACTOR procedure (SAS 9.2 statistical package).

TABLE I

Description of the eight equations tested to obtain the best fit of the parameters in the nonlinear regression of the Gompertz model.

\begin{tabular}{ccccccccc}
\hline Parameters & M1 & M2 & M3 & M4 & M5 & M6 & M7 & M8 \\
\hline$a$ & $a i$ & $a$ & $a i$ & $a i$ & $a$ & $a i$ & a & a \\
\hline $\mathrm{b}$ & $\mathrm{bi}$ & $\mathrm{bi}$ & $\mathrm{b}$ & $\mathrm{bi}$ & $\mathrm{b}$ & $\mathrm{b}$ & $\mathrm{bi}$ & $\mathrm{b}$ \\
\hline $\mathrm{k}$ & $\mathrm{ki}$ & $\mathrm{ki}$ & $\mathrm{ki}$ & $\mathrm{k}$ & $\mathrm{ki}$ & $\mathrm{k}$ & $\mathrm{k}$ & $\mathrm{k}$ \\
\hline
\end{tabular}

$\mathrm{i}=$ different parameters tested for males and female

\section{RESULTS}

This is the first study where were estimated the body growth pattern of tambaqui (C. macropomum) and is possible observed that each tissue has patterns and growth rate different, which featuring an allometric body growth (Fig. 1). Length and body height were the first traits achieved the maximum growth rate, followed by head length, weight and body width (Fig. 1a; 1c). Thereby, we can determine that the bone tissue was deposited first followed muscle tissue (Table II), indicated by the order in days to reach the inflection point for head length (236-246 days), length (256 days), width (256-346 days), height (366-376 days) and body weight (486 days).
The curves study showed growth patterns similar between males and females for length and body width (Fig. 1a; 1b). Width and body length were better fitted at one only growth curve for males and females. Although the maximum growth rate of $0.00317 \mathrm{~cm} /$ day for body width has been detected at 366-376 days, it was not possible see the point of inflection in the growth curve. Inversely, head length, weight and body height showed different estimation for males and females (Fig 1c; 1d; 1e). Were observed differences of the female's asymptotic values $(a)$ and age at inflection point $(k)$ in comparison to males; fitting curves with different estimates for the parameters at each sex (M3 equation). The body length showed a slow growth, going from 46 to $55 \mathrm{~cm}$ at $2 \mathrm{~kg}$ and $4 \mathrm{~kg}$, respectively (Fig. 1b). The maximum growth rate of $0.12 \mathrm{~cm}$ was reached in 256 days (Table II).

The body weight showed a growth faster than morphometric traits. Muscle deposition was different to males and females (Fig. 1c). The males weighted on average $77.3 \mathrm{~g}$ less at the $2 \mathrm{~kg}$ and $257.5 \mathrm{~g}$ less than females at the $4 \mathrm{~kg}$ (Table III). The difference between males e females is evidenced through of growth maximum rate, 8.66 $\mathrm{g}$ at 476 days reached by males and $9.34 \mathrm{~g}$ at 486 days reached by females (Table III). Differentially, the difference between males and females for body height was small, lower than $1 \mathrm{~cm}$ in both $2 \mathrm{~kg}$ and $4 \mathrm{~kg}$ (Table III). The maximum growth rate reached was 0.0718 and $0.0737 \mathrm{~cm}$ for males and females, respectively, obtained at 256-346 days.

TABLE II

Maximum growth rate and estimated days to inflection point for body weight (BW), body length (BL), length of head ( $\mathrm{LH})$, body width (BWi) and body height $(\mathrm{BH})$ in tambaqui

(Colossoma macropomum).

\begin{tabular}{ccccc}
\cline { 2 - 5 } & \multicolumn{3}{c}{ Male } & \multicolumn{3}{c}{ Female } \\
\hline Traits & & Days & Days \\
\hline BW (g/day) & 8.66 & 476 & 9.34 & 486 \\
\hline BL (cm/day) & 0.1274 & 256 & 0.1274 & 256 \\
\hline LH (cm/day) & 0.0325 & $246-236$ & 0.03339 & $246-236$ \\
\hline BWi (cm/day) & 0.00317 & $366-376$ & 0.00317 & $366-376$ \\
\hline BH (cm/day) & 0.0718 & $256-346$ & 0.0737 & $256-346$ \\
\hline
\end{tabular}


a

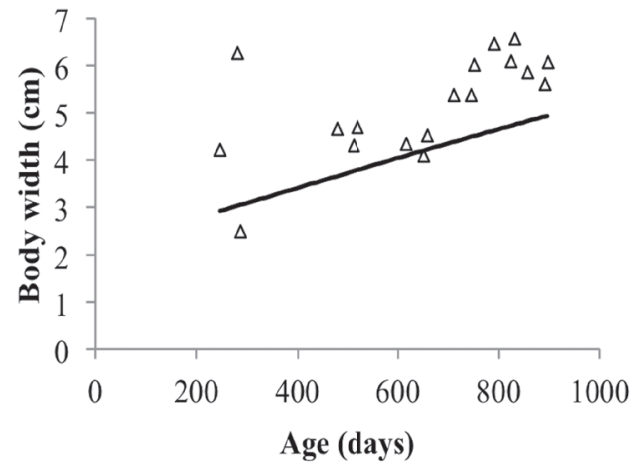

C Female: $5010 * \operatorname{EXP}(-\operatorname{EXP}((-0.00507 *(t-488))))$

Male: $4641 * \operatorname{EXP}(-\operatorname{EXP}((-0.00507 *(t-474.7))))$

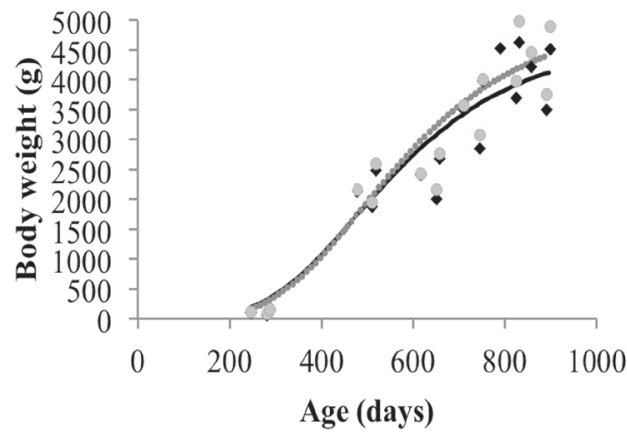
Female: $16.6252 * \operatorname{EXP}\left(-\operatorname{EXP}\left(\left(-0.00546^{*}(\mathrm{t}-285.1)\right)\right)\right)$ Male: $16.183 * \operatorname{EXP}(-\operatorname{EXP}((-0.00546 *(t-285.1))))$

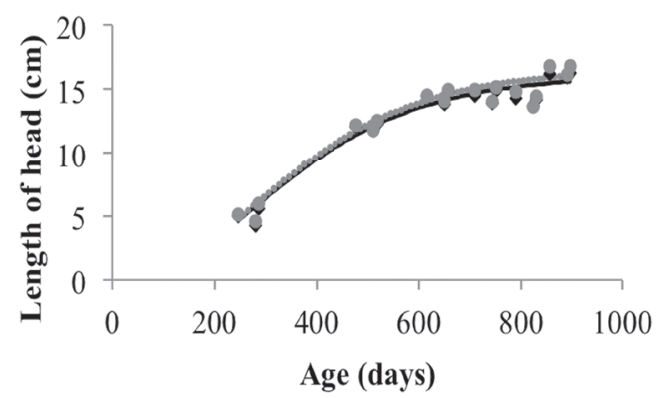

b $\quad 58.4772 * \operatorname{EXP}(-\operatorname{EXP}((-0.00592 *(t-282))))$

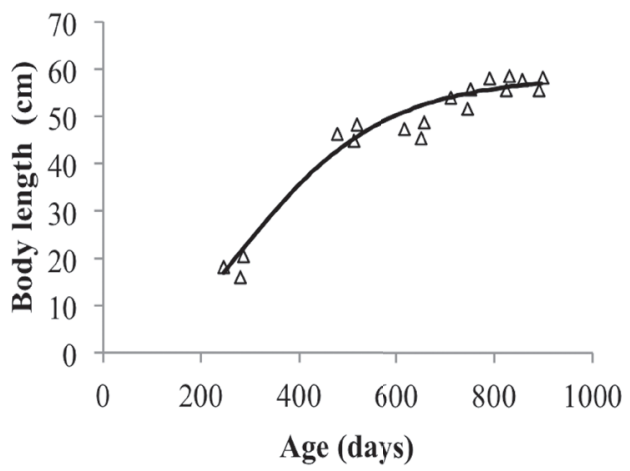

d Female: $21.2971^{*} \operatorname{EXP}(-\operatorname{EXP}((-0.00941 *(t-297))))$ Male: $20.7614 * \operatorname{EXP}(-\operatorname{EXP}((-0.00941 *(t-297))))$

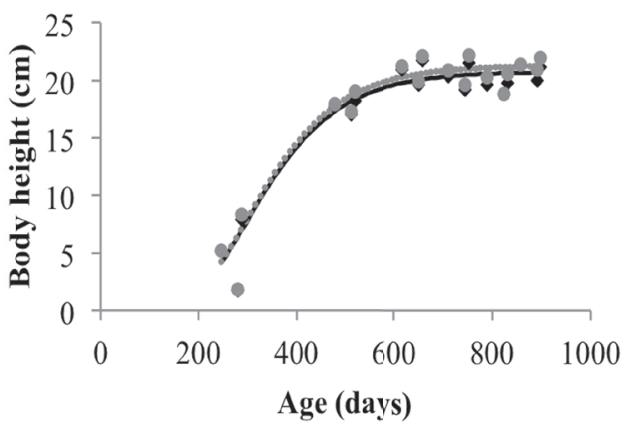

Figure 1 - Growth profiles body according to adjusted of the Gompertz nonlinear model at 896 days: body width (a); body length (b); body weight (c); head length (d) and body height (e) at function of age in tambaqui (Colossoma macropomum). Data females are represented by gray color and males are represented by black color. The triangles represent the data for males and females together.

The growth curve for the head length showed a slow growth (Fig. 1e). Although measures very similar growth, different curves were adjusted for each sex. The maximum growth rate reached was 0.0325 for males and 0.0339 to females (Table
II). There were differences at the estimates of $b$ parameter for body height and head length (M6 equation) indicating a constant exponential growth different between males and females (Fig. 1d; 1e). 
TABLE III

Mean \pm standard deviation for weight and morphometric traits of the weight at slaughter performed currently, $\pm 2 \mathrm{~kg}$ (516 days) and $\pm 4 \mathrm{~kg}$ (800 days), in Colossoma macropomum.

\begin{tabular}{ccccc}
\hline \multirow{2}{*}{ Traits } & \multicolumn{2}{c}{516 days } & \multicolumn{2}{c}{800 days } \\
\cline { 2 - 5 } & Male & Female & Male & Female \\
\hline Body weight $($ grams) & $2140.31 \pm 387.1$ & $2217.66 \pm 388.7$ & $3887.30 \pm 113.7$ & $4144.82 \pm 120.1$ \\
\hline Body height $(\mathrm{cm})$ & $17.65 \pm 0.99$ & $18.1 \pm 1.05$ & $20.59 \pm 0.77$ & $21.12 \pm 0.80$ \\
\hline Length of head $(\mathrm{cm})$ & $12.02 \pm 0.58$ & $12.2 \pm 0.56$ & $15.27 \pm 0.55$ & $15,69 \pm 0.54$ \\
\hline Body width $(\mathrm{cm})$ & $4.54 \pm 0.33$ & $4.66 \pm 0.32$ & $5.61 \pm 0.30$ & $5.68 \pm 0.31$ \\
\hline Body length $(\mathrm{cm})$ & $46.23 \pm 2.5$ & $46.56 \pm 2.53$ & $55.91 \pm 1.78$ & $55.89 \pm 1.8$ \\
\hline
\end{tabular}

Were carried out the principal component analysis (PCA) up to $\pm 2 \mathrm{~kg}$, reached at 516 days. The PCA showed that animals with greater body length and length head showed lower body height. Being the head length and body length the traits of the most influence the body weight and daily weight gain until $2 \mathrm{~kg}(P<0.001)$ (Fig. 2).

\section{DISCUSSION}

The initial hypothesis was there no difference in growth among males and females; however, our results demonstrate there is a greater body growth of females evidenced after of reproductive maturation ( \pm 846 days). From these results is possible to corroborate the observations reported by fish farmers, that the females grow faster than males after reproductive maturation (Vieira et al. 1999).

Analyze growth curves is a complex because the evolution of growth over time is nonlinear, and it is affected by genetic and environmental effects (Ibáñez-Escriche and Blasco 2011). However, from this date is possible to estimate the maximum growth rate and, thus, fit the better slaughter age for each sex. The shape of body, sex and body weight are very important in choosing the processing performed by the industry, as it influences the operations of beheading, gutting and cleaning, besides influencing the final yield of the processing (Carneiro et al. 2004, Contreras-Guzmán 1994, Faria et al. 2003).
According the processing industry the slaughter weight of this species current is $2 \mathrm{~kg}$, which was achieved at 516 days of cultivation. In this point, is possible to observe at both sexes the same body growth pattern (Fig. 1c); thereby, indicating males and females for fish farming (Table III). On the other hand, the females showed a maximum growth rate for body weight higher than males, 9.34 and $8.66 \mathrm{~g} /$ day, respectively, achieved at different days of cultivation, 476 days to males and 486 days to females (Table II).

Although most of the production Tamaquabe aimed at industry with an average weight $\pm 2 \mathrm{~kg}$, there is a market demand directed to the animals above the $\pm 5 \mathrm{~kg}$. To meet the demand of this niche market for large animals, the cultivation of female's tambaqui is the most indicated due to its capacity growth faster than males. Currently, the market for larger animals is stocked mainly with extractive fishing at the Amazon Basin Rivers. However, overexploitation generates a decrease of the natural stocks of animals this size in the rivers of region, indicating the depletion of natural stocks of these species (Da Silva Batista and Petrere Junior 2003). In Brazil, the Environment Ministry classified the species as overexploited or threatened by overexploitation (statute no. 5 of May 21, 2004).

In this context, cultivation of tambaqui is of utmost importance in the conservation this species and supplying the consumer market. Thus, the understanding of animal growth has strategic 


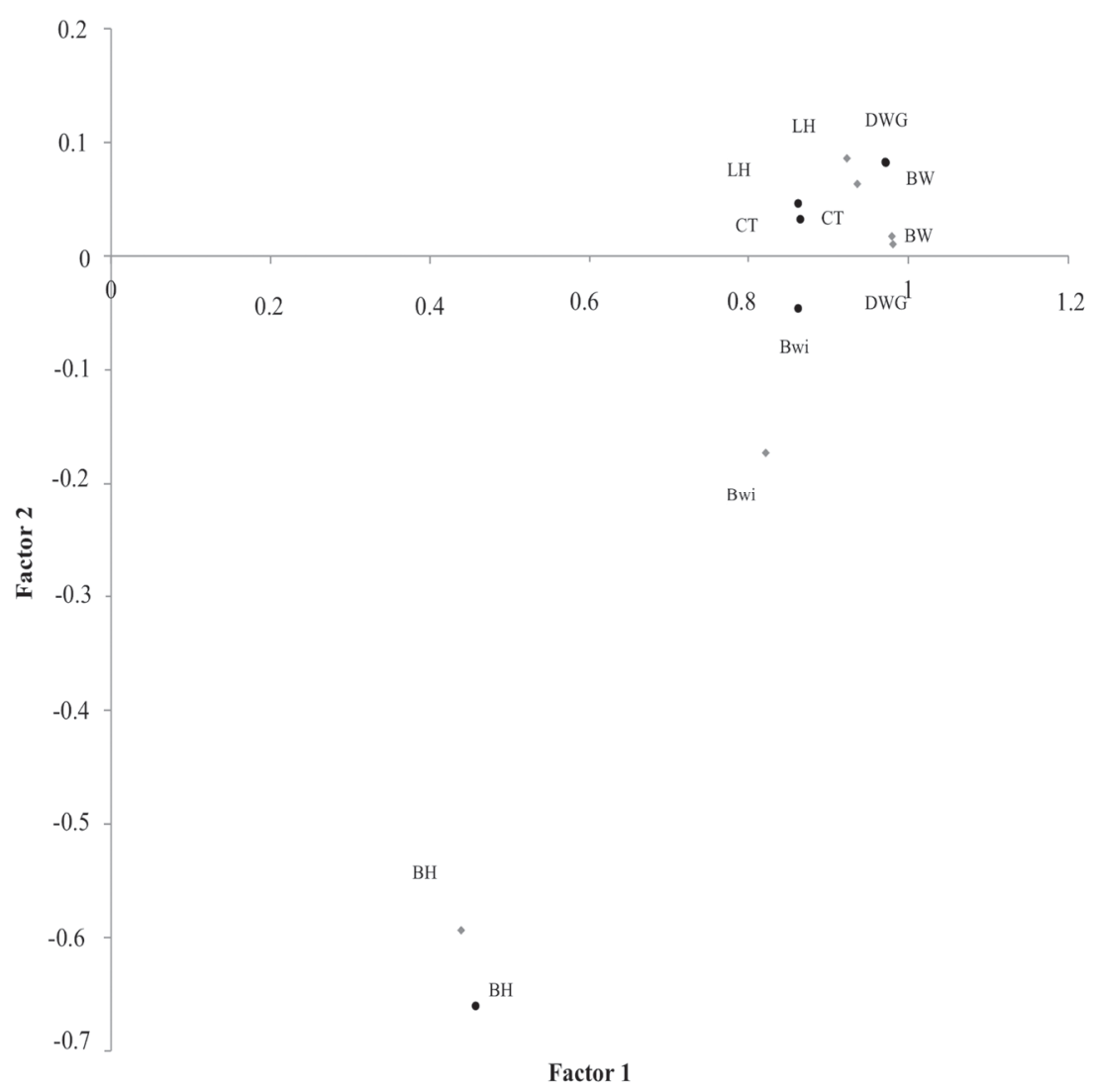

Figure 2 - Principal Component Analysis (PCA) on growth traits of tambaqui (Colossoma macropomum). Factors 1 and 2 represent $86 \%$ of accumulated variance; body weight (BWE), daily weight gain (DWG), body width (BWi), body height (BH), length of head (LH) and body length (BL) for 516 days of age $( \pm 2 \mathrm{~kg})$. Data of females are represented at black and males are represented at grey.

importance for obtaining maximum growth of animals, optimizing the slaughter age for each sex.

\section{CONCLUSIONS}

There differences in growth patterns between adult male and female evidenced by the different curves fitted, indicating the existence of sexual dimorphism of this specie. The understanding of differences observed on body growth and growth rates between the sexes is important for more success in the cultivation strategy employed. Were showed differences at the maximum growth rate between the sexes suggesting the need to adapt the actual production system to use the maximum growth potential of each sex.

\section{ACKNOWLEDGMENTS}

The authors gratefully acknowledge the Empresa Brasileira de Pesquisa Agropecuária (Embrapa), technical team of Delicious Fish and Conselho Nacional de Desenvolvimento Científico e Tecnológico (CNPq).

\section{RESUMO}

Foi avaliado o padrão de crescimento entre fêmeas e machos de tambaqui por meio do modelo de regressão não linear de Gompertz. Foram mensuradas cinco características de importância econômica em 145 animais durante os três anos, totalizando 981 de dados morfométricos analisados. Curvas diferentes foram ajustadas entre machos e fêmeas para peso corporal, 
altura e comprimento da cabeça e apenas uma curva para a largura e comprimento do corpo foi ajustada para ambos os sexos. O peso assintótico $(a)$ e taxa de crescimento relativo à maturidade $(k)$ foram diferentes entre os sexos nos animais com $\pm 5 \mathrm{~kg}$; peso de abate praticado por um nicho específico do mercado, muito rentável. No entanto, não houve diferença entre machos e fêmeas de até $\pm 2 \mathrm{~kg}$; peso de abate estabelecido para abastecer o maior mercado consumidor. As fêmeas apresentaram maior peso do que os machos $( \pm 280 \mathrm{~g})$, sendo estas mais indicadas para fins de piscicultura definidos para o nicho de mercado de animais maiores. Em geral, os machos apresentaram menor taxa de crescimento $(8,66 \mathrm{~g} / \mathrm{dia})$ do que as fêmeas $(9,34 \mathrm{~g} /$ dia), entretanto, alcançaram a taxa máxima de crescimento mais rápido do que as fêmeas, 476 e 486 dias, respectivamente. A altura e comprimento do corpo são as características que mais contribuíram para o peso aos 516 dias $(P<0,001)$.

Palavras-chave: curva de Gompertz, crescimento corporal, taxa de crescimento máximo, ponto de abate.

\section{REFERENCES}

ARANGO J AND VAN VLECK LD. 2002. Size of beef cows: early ideas, new developments. Gen Mol Res 1: 51-63.

CARneIro PCF, AZEVEDO HC, SANTOS JP AND MARIA AN. 2012. Cryopreservation of tambaqui (Colossoma macropomum) semen: extenders, cryoprotectants, dilution ratios and freezing methods. Cryo Letters 33: 385-393.

CARnEIRO PCF, MiKos JD, BENDHAK F AND IGNACIO SA. 2004. Processamento do jundiá Rhamdia quelen: rendimento de carcaça. Rev Acad Ciênc Agrár Ambient 2: $11-17$.

Contreras-GuzMán E. 1994. Bioquímica de Pescados e Derivados. FUNEP, Jaboticabal, 409 p.

CORRÊA CF, DE AGUIAR LH, LUNDSTEDT LM AND MORAES G. 2007. Responses of digestive enzymes of tambaqui (Colossoma macropomum) to dietary cornstarch changes and metabolic inferences. Comp Biochem Physiol A Mol Integr Physiol 147: 857-862.

COSTA LRF, BARTHEM RB, ALBERNAZ AL, BITTENCOURT MM AND VILLACORTA-CORREA MA. 2013. Modelling the growth of tambaqui, Colossoma macropomum (Cuvier, 1816) in floodplain lakes: model selection and multimodel inference. Braz J Biol 73: 397-403.

Da Silva Batista V AND Petrere Junior M. 2003. Characterization of the commercial fish production landed at Manaus, Amazonas State, Brazil. Acta Amaz 33: 53-66.
FARIA RHS, SOUZA MLR, WAGNER PM, POVH JA AND RIBEIRO RP. 2003. Rendimento do processamento da tilápia do nilo (Oreochromis niloticus Linnaeus, 1757) e do pacu (Piaractus mesopotamicus, Holmberg 1887). Acta Sci 25: 21-24.

FIALHO FB. 1999. Interpretação da curva de crescimento de Gompertz. Comun Téc 237: 1-4.

Gomes F, SCHNEIdER H, BARRos C, SAMPAio D, HASHimoto D, PORTO-Foresti F AND SAMPAIO I. 2012. Innovative molecular approach to the identification of Colossoma macropomum and its hybrids. An Acad Bras Cienc 84: 517-526.

GOMIERO JSG, RIBEIRO PAP, FERREIRA MW AND LOGATO PVR. 2003. Rendimento de carcaça de peixe matrinxã (Brycon cephalus) nos diferentes cortes da cabeça. Ciênc Agrotec 27: 211-216.

HAMOY IG AND SANTOS S. 2012. Multiplex PCR panel of microsatellite markers for the tambaqui, Colossoma macropomum, developed as a tool for use in conservation and broodstock management. Genet Mol Res 11: 141-146.

IBÁÑEZ-ESCRICHE N AND BLASCO A. 2011. Modifying growth curve parameters by multitrait genomic selection. J Anim Sci 89: 661-668.

KNIZETOVA H, HyANEK J, KNIZE B AND ROUBICEK J. 1991. Analysis os growth-curves of fowl. 1. Chickens. Br Poult Sci 32: 1027-1038.

MARCUSCHI M, ESPÓSITO TS, MACHADO MFM, HIRATA IY, MACHADO MFM, Silva MV, CARVALHO JR LB, Oliveira V AND BEZERRA RS. 2010. Purification, characterization and substrate specificity of a trypsin from the Amazonian fish tambaqui (Colossoma macropomum). Biochem Biophys Red Commun 396: 667-673.

MARiA A, AZEVEdo H, SANTOS J AND CARNEIRO P. 2012. Hormonal induction and semen characteristics of tambaqui Colossoma macropomum. Zygote 20: 39-43.

Ministério DA PESCA E AQUiCUlturA. 2013. Boletim estatístico da pesca e aquicultura: Brasil 2011.

OLIVA-TELES A. 2012. Nutrition and health of aquaculture fish. J Fish Dis 35: 83-108.

PENNA MA, VILlaCORTA-CORREA MA, WALTER T AND PETRERE-JR M. 2005. Growth of the tambaqui Colossoma macropomum (Cuvier) (Characiformes: Characidae): which is the best model?, In: Braz J Biol Brazil, p. 129-139.

REGAZZI AJ AND SILVA CHO. 2004. Teste para verificar a igualdade de parâmetros e a identidade de modelos de regressão não-linear. I. Dados no delineamento inteiramente casualizado. Rev Mat Estat 22: 33-45.

VIEIRA EF, ISAAC VJ AND FABRÉ NN. 1999. Biologia reprodutiva de Tambaqui. Acta Amaz 29: 265-638. 
